University for Business and Technology in Kosovo

UBT Knowledge Center

UBT International Conference

2014 UBT International Conference

Nov 8th, 5:00 PM - 5:15 PM

\title{
Sales approach in driving pharmaceutical industry in Kosovo
}

Uragan Alija

University for Business and Technology, uragan.alija@ubt-uni.net

Follow this and additional works at: https://knowledgecenter.ubt-uni.net/conference

Part of the Business Commons

\section{Recommended Citation}

Alija, Uragan, "Sales approach in driving pharmaceutical industry in Kosovo" (2014). UBT International Conference. 52.

https://knowledgecenter.ubt-uni.net/conference/2014/all-events/52

This Event is brought to you for free and open access by the Publication and Journals at UBT Knowledge Center. It has been accepted for inclusion in UBT International Conference by an authorized administrator of UBT Knowledge Center. For more information, please contact knowledge.center@ubt-uni.net. 


\title{
Sales approach in driving pharmaceutical industry in Kosovo
}

\author{
Uragan Alija \\ University for Business and Technology \\ uragan.alija@ubt-uni.net
}

\begin{abstract}
Ongoing competition between international pharma companies and local companies has brought the pharmaceutical sales and marketing approach in Kosovo in a very complex level. In particular, the paper looks at the perspective of a local pharmaceutical producer in Kosovo facing challenges in the pharmaceutical market in Kosovo. Current methodology of sales and marketing approach needs to be revisited and strategies of these companies need to include more innovative approaches in order to institute a differentiated approach between these companies. This paper looks at the current approach of companies, positive and negative remarks of these approaches of perception by both medical doctors and pharmacies. This document concludes with recommendations for improvement in sales approach, marketing approach of communication, use of industry leaders in explaining the recent trends and research, continuous facilitation of conferences and seminars in the topic of general interest.
\end{abstract}

Keywords: Sales Methodology, Pharmaceutical Industry Kosovo, Kosovo medicine manufacturer

\section{Introduction}

Kosovo Medicines Agency in 2014 published the first report on the consumption of drugs in Kosovo for the period 2011-2013. In the same report, it provided information about the pharmaceutical market in Kosovo. According to this report, in Kosovo there are two manufacturers of medicinal products, both of them being certified with Good Practice Manufacturing (GMP). One of these manufacturers has been subject to the study of sales methodology and environment in Kosovo. According to the same report, there are 81 distributors of products and 52 distributors of medical devices, who are the main competitors to the two local manufacturers. These pharmaceutical products and medical devices are sold through a network of 519 pharmacies (KMA, 2014) throughout Kosovo. In addition, according to internal information of one of the manufacturers in Kosovo there are approximately 11,000 doctors responsible for drug prescription.

This document looks at the perspective of a local pharmaceutical producer in Kosovo facing challenges in the pharmaceutical market in Kosovo, mainly with a huge global competition. The focus is placed on the sales and marketing approach employed by the industry as a whole and the focus that the manufacturer should place in the industry.

\section{Sales and marketing in the pharmaceutical sector}

Charles Schwab, a worldwide known entrepreneur once said "We are all salespeople every day of our lives, selling our ideas and enthusiasm to those with whom we come in contact" (Havemann \& Batten, 2013).

Marketing nowadays remains considered as a vehicle of a service oriented company. Moving from production promotion, the focus is in identifying and interpreting customers' needs into prepositions of value to their needs and wants. In this regard, there has been a continuous change of marketing 
definition in regards to American Marketing Association (AMA), a well-known North-American organization whose definitions are well regarded within Academia (Gronroos, 2006). In 2004, AMA published this definition of marketing "Marketing is the process of planning and executing the conception, pricing, promotion, and distribution of ideas, goods, and services to create exchanges that satisfy individual and organizational goals." (Kotler \& Keller, 2006). Due to the changes in the marketing and business environment, AMA re-defined its marketing definition and in 2007 published the following "Marketing is the activity, set of institutions, and processes for creating, communicating, delivering, and exchanging offerings that have value for customers, clients, partners, and society at large." ${ }^{49}$ Main highlights of this definition were values, customer relationship and stakeholders.

If marketing is considered responsible to communicate about the value, than sales can be considered as responsible to deliver this value to the customer. Kotler \& Keller (2006) define sales function as closest to the customer, therefore the success of any modern organization lies on its core which is the relationship with its customers. According to AMA, sales is about "any of a number of activities designed to promote customer purchase of a product or service. Sales can be done in person or over the phone, through e-mail or other communication media. The process generally includes stages such as assessing customer needs, presenting product features and benefits to address those needs and negotiation on price, delivery and other elements." In this regard, in specific to pharmaceutical industry, sales people would market and sales representatives of companies who would be responsible to provide information about their value preposition to doctors and other members of the value chain. Dixon \& Tanner (2012) view salespeople "as the architect for change in their customers' worlds, therefore in the case of local manufacturers, these representative would need to play a key role in convincing about the quality and perception of local products.

In particular regarding role of sales in the pharmaceutical world, according to Stevens Institute of Technology, most important activities are: Face-to-face visits to doctors or responsible staff for purchases/procurement in order to introduce new solutions and new products, distribution of samples, explain the proper use of products, building the relationship with doctors and the medical staff with differentiated approach as "required for optimal solutions". This approach would be beneficial also for the medical staff and doctors as they would have the opportunity to receive first-hand information about the products from the manufacturer as well as learn new information.

\section{Application of sales and marketing}

This research involved interviewing sales and marketing representatives of the local manufacturer in identifying the process they use, challenges they face and come up with recommendations on improving the methodology. According to Creswell's (2007) the range of respondents should be within a range of 3-10 individuals. In this process, 3 doctors, 3 pharmacists and several other sales staff were interviewed. According to respondents, when they meet with doctors in presenting their solutions, they receive both positive and negative feedback. Main positive comments are related to be able to test samples, receive new information and follow the trends, be informed with the production process and also have the opportunity to see the process as the manufacture is in Kosovo. On the negative aspect, the feedback received is that there are many representative who come for similar solutions, than different representatives of the same company, lack of new information, interrupting the work with patients, lack of sufficient expertise from marketing and sales representatives and sometimes lack of sufficient samples. Regarding the use of marketing communication to inform about benefits of manufacturer solutions, it can only be used for over the counter products.

49 Dictionary. American Marketing Association. Date retrieved, 17 December 2013: https://www.ama.org/resources/Pages/Dictionary.aspx?dLetter=M 
From the conducted interviews with sales and marketing representatives, the interview of main responsible for marketing and sales, the strategy of local manufacturer should be focused on improving the sales approach with medical staff and with pharmacies.

Some of the improvements in the relationship with medical staff could be the investment in bringing experts of the field, known at least in the region. These are experts that will influence "opinion" and will bring latest know-how. Sponsor conferences with most important and actual topics of interest and apply the DAPA - 4 steps sales model (Iftikhar, 2011) by focusing on defining doctor's requirements, making sure that these requirements are understood, identify ways of proving that solutions work and receive the acknowledgment from the doctor that the solution meets the requirements.

While suggestions to improve the sales model with pharmacies could be focused on presenting a sale concept which is not focused on products - rather on solutions. Invest in portfolio programs that bring value to the pharmacy, provide training in new pharmacy trends, and share information about the production process. In addition, make the best use of an integrated marketing communication program by sharing samples at the same time with doctors and provide the related communication to pharmacies as well. Focus on providing sales systems that are based on incentives, targets, and competitions. Provide personalized service to each pharmacy as if each pharmacy was the only customer the company has. Make the best use of a CRM application through a loyalty scheme

\section{Main limitations}

This study focused on a smaller range of respondents and focused only in a single case, the manufacturer in Kosovo. Potential for future research would be to involve the other manufacturers as well as other distributors. In addition, the working was limited only to Kosovo, therefore the research could be expanded to other neighboring countries.

\section{References}

1. Creswell, J. (2007). Qualitative Inquiry \& Research Design- Choosing Among Five. Thousand Oaks, CA: SAGE Publications, Inc.

2. Dixon, A. L., \& Tanner, J. F. (2012). Transforming Selling: Why it is Time to Think Differently about Sales Research. Journal Of Personal Selling \& Sales Management, 32(1), 9-14.

3. Gronroos, C. (2006). On defining marketing: finding a new roadmap for marketing. Marketing Theory, 6(4), 395-417.

4. Havemann, S, Batten, J (2013). The Excellent Persuader. Wipf and Stock Publishers

5. Iftikhar, K (2011). Pharmaceutical Selling Skills

6. KAM Kosovo. (2014). Konsumi i Barnave në Kosovë. Drug Consumption in Kosovo. 2011-2013.

7. Kotler, P, Keller, K (2006). Marketing Management. 12th Edition: Prentice Hall.

8. Stevens Institute of Technology. Marketing and Sales Roles in the Pharmaceutical Industry. 